\title{
Social and Economic Components of Well-being
}

\author{
N.V. Kozlova ${ }^{a}$, M.S. Polonskaya ${ }^{a}$ \\ * Corresponding author: N.V. Kozlova, nvkozlova@tpu.ru \\ ${ }^{a}$ Tomsk Polytechnic University, 30 Lenin av., Tomsk, 634050,E-mail: nvkozlova@tpu.ru
}

\begin{abstract}
http://dx.doi.org/10.15405/epsbs.2016.02.19

The article examines the relationship between economic development and social components of human well-being. The definitions of basic concepts that describe the position of the person in the economic environment are given. The authors examine the different components of well-being, both objective and subjective, based on the personal perception of a person. Economic growth on the one hand and social policy on the other should contribute to improving the living standards of the population. A man should feel comfortable and safe in the economic environment not only due to the social support of the state. It is very important to have a sense of self-realization for a man, self-worth, which he can attain with close people in a family.
\end{abstract}

(C) 2016 Published by Future Academy www.FutureAcademy.org.uk

Keywords: Well-being; welfare; standard of living; quality of life.

\section{Introduction}

It is a well-known fact that the growing economy provides a material basis for progress in social sphere, through increase in social production changing conditions of life both a separate person, and society as a whole. But economic achievements are not the aims of economic growth. The main idea is to increase the level of quality of human life. Life quality as an estimation of well-being and it depends both on economic forces, and subjective value of a person of his place and a role in an economic life. Life quality parameters become independent factors of economic development of society. However, the material basis is the important component of well-being and it needs redistribution of results of economic growth in view of requirements of various population groups. It is necessary to state economic regulation and effective social policy for this purpose. This policy should provide ways of 
eISSN: 2357-1330

Selection \& Peer-review under responsibility of the Conference Organization Committee

achievement of life improvement of population on the most significant positions, such as increase in incomes of population, security habitation and public health services.

\section{Problem statement}

The basic parameters of economic growth in economic theory are considered to be increase in the real income in economy and its growth counting upon a soul of population. The first parameter is used, as a rule, at an estimation of change rates of economic potential of country, the second - as one of parameters of population living standard and comparisons of life standard in the various countries and regions.

The problem of economic growth and its rates is one of the major concerns in macroeconomic. Its studying allows to understand, first, the reasons of distinctions in a standard of living between the various countries during the same period and inside the country during the different periods; second, to reveal factors of economic growth; third, to define conditions of preservation of a high living standard in the countries which have already reached it, and, at last, to develop measures of a state policy on maintenance and acceleration of economic growth.

The main objective of economic growth is growth of welfare and increase in national wealth. It is believed, that than more industrial potential of the country is and higher the rates of economic growth are, so the higher a standard of living and welfare of citizens, see Table 1 (www.gks.ru).

Table 1. GDP of Russia (prices 2008)

\begin{tabular}{lccccc}
\hline & 2008 & 2009 & 2010 & 2011 & 2012 \\
\cline { 2 - 6 } GDP, bill. rub. & 41276.8 & 38048.6 & 39762.2 & 41457.8 & 42882.1 \\
\hline
\end{tabular}

Economic growth and welfare of a society are closely interconnected, as economic achievements in themselves are not the purposes of economic growth, but the final aim is to increase a level and quality of human life. Progress should be estimated on a degree of clearing of mankind from poverty and famine, i.e. growth of well-being of mankind as a whole.

Achievement of high results in public and economic development at all does not mean security of the population in the social blessings and conditions for a worthy life. According to experts of the United Nations for today more than 1 billion persons live in conditions of extreme poverty and famine. Therefore economic parameters, for example, rate of growth of gross national product do not give the real representation about a level of well-being of population.

A certain view of the population welfare can give an indicator of household income, which is a component of GDP. The dynamics of this index in Russia is showed in Table 2 (www.gks.ru).

Table 2. Household income (current prices)

\begin{tabular}{|c|c|c|c|c|c|}
\hline & 2008 & 2009 & 2010 & 2011 & 2012 \\
\hline Income, mill. rub. & 23857945 & 25407228 & 28501551 & 33797990 & 37929269 \\
\hline $\begin{array}{l}\text { which includes } \\
\text { salary }\end{array}$ & 11648458 & 11815773 & 13385633 & 15478540 & 17609982 \\
\hline
\end{tabular}


http://dx.doi.org/10.15405/epsbs.2016.02.19

eISSN: 2357-1330 / Corresponding Author: N.V.Kozlova,E-mail:nvkozlova@tpu.ru

Selection and peer-review under responsibility of the Organizing Committee of the conference

These data show some steady increase year by year, where is an increasing sum of salary plays the biggest role which is the main source of income for the majority of Russians.

\section{Research questions}

Some terms describing position of a person in the economic environment, such as "standard of living", "quality of a life", "well-being" and "welfare" have not only the economic contents, but also are closely connected to subjective perception by a person of the surrounding validity.

Standard of living of population gives the size of real incomes, characterizes a consumption level of material benefits and services that are used by population, a development degree of medical, cultural and consumer services of citizens, a condition of the surrounding of the natural environment where person lives.

Welfare is a degree of people security with the prize of life, means of existence. Welfare characterizes a standard of people living.

Concepts "welfare" and "standard of living" are frequently used as synonyms as its basically coincide under the contents. However, the concept "standard of living" is treated more widely as includes elements of social support of the state. Thus, the concept of a well-being standard is not identically to the concept of a standard of living. The concept "standard of living" is wider and is characterized not by only volume of real incomes counting upon a soul of population, but also a degree of people security with the material and spiritual blessings.

Quality of life is an estimation of some set of conditions and characteristics of a human life, usually is based on its own degree of satisfaction with these conditions and characteristics (Kilchukova A.L., 2012).

Parameters of life quality are social - a steady position of a person, their social well-being. Active and independent factors of economic development, as work, capital, technology, business are the factors influencing accumulation of a human capital.

Besides in economy, medicine, sociology are used such concept as "well-being". These concepts are wider and include subjective factors of satisfaction of spiritual and cultural needs. Well-being is condition of a person or an objective situation when a person has all that favorably characterizes their life in opinion of associates, their relatives and themselves. This condition of a person sincere comfort, includes not only material security, and also happiness in love and home life. Some researchers mark, that quality of life as a subjective value of well-being does not depend on material maintenance.

Economic growth is inextricably related with scientific and technical progress that is expressed in perfection of technical equipment and technologies of production occurrence of the new goods and services. As consequence, this moves into change of person needs, increase the requirements in comfort of dwelling and rest conditions. From the part of goods manufacturers and services the analysis and the account of changes in demand of population is a starting point for the decision about modernization of existing manufactures and creation new ones. Thus, the growing economy gives a material basis of progress in social sphere, through increase in a social production by means of changing conditions of life both a separate person, and a society as a whole. 


\section{Models}

Now the social orientation is one of the major characteristics of the advanced economic system. Any modern state should incur functions of economic regulation, including social protection of population. Besides experience of the advanced countries shows, that without systematic development of social sphere directed by the state, science and education, development and introduction in manufacture of new technologies dynamical development of economy, a high standard of living, maintenance of social stability and security of the population are impossible.

It is possible to allocate two basic types of the countries among the modern European states such as the countries with essentially various ratio of a share of participation of the state, a worker and an employer in financing social programs. On the one hand, these are the countries that are socially focused on market economy where budgetary deductions and insurance payments of a worker and an employer on social actions are approximately equal, and the basic channels of redistribution are state private (but are controlled by the state) social - insurance funds. As an example one may show France or Germany. But on the other hand, these countries of so-called market socialism, such as Sweden, and Denmark where the significant part of charges on social needs is incurred with the state, and the basic channel of redistribution is the state budget. Thus, the financial role of the state in realization of social programs and actions can be various (Samaruha V.I., Gulyaeva L.V., 2011).

In Russia scientific development and the scientific analysis in the field of the theory of the social state while are at an initial stage of research.

At the same time it is necessary to give attention to the sources providing material welfare. One of the major sources is incomes of citizens. To the most widespread macroeconomic parameters describing incomes of population, now carry real available incomes of domestic facilities, average monetary incomes per capita, the minimal and average wages, an average size of pensions, see Table 2.

Research of sources of citizens' incomes are very important for an estimation of such category, as welfare as it represents connection between these categories. From this point of view a parameter « gross national product per capita » cannot correctly reflect a level of social welfare as the components included in gross national product, for example, the investment, do not render the direct influence on well-being.

In the Russian economic literature such parameter of well-being is considered as an index of economic aspects of well-being which is calculated on the basis of personal consumption items. From the point of authors' view, this parameter reflects personal well-being of citizens more accurately, than a parameter of the general consumption as excludes a public sector which the most part of consumption does not render the direct influence more precisely and has intermediate character. At the same time, charges on public health services and educational services are included in an index because influence on increase of welfare directly (Kizhikina V.V., 2012).

\section{Findings}

Quality of life is estimated on a set of criteria, including real incomes and charges of population, security habitation, availability of medical aid and education. Researches of the Russian scientists have shown, that for the period of 1992-2010 years the growth of a soul real average monetary incomes 
http://dx.doi.org/10.15405/epsbs.2016.02.19

eISSN: 2357-1330 / Corresponding Author: N.V.Kozlova,E-mail: nvkozlova@tpu.ru

Selection and peer-review under responsibility of the Organizing Committee of the conference

almost has three times exceeded growth of real salary. It shows non-uniformity of increase in factorial incomes that carries out to the big stratification of population. During this period the national project "Public health services" was realized which provided the big state assignments in medicine. Nevertheless, these charges are some times less than similar charges in the countries of the Western Europe. At the same time some private financing of medical services in Russia considerably exceeds the West-European level. Concerning an educational level of population, for this period, it has increased very essentially though, by expert estimations, availability of services in the sphere of education, as well as in the sphere of public health services in Russia has decreased.

Well-being is a multilevel category and incomes of a person are only its part. Also satisfaction of their life is very important for people, as well as their confidence of social security, opportunity of selfrealization. Parameters of well-being are influenced with huge amount both objective, and subjective factors (Leontjev D.A., 2011).

Problem of economic well-being is one of the most complex and is still not well studied areas of economy. Experts are included into the contradiction with each other at definition of this concept. Except a question about what is an economic well-being, not less sharply stands a problem of laws its structural organization and measurement.

Traditional economic models of utility appeared insufficient for understanding of how do economic forces influence on fortune and subjective people well-being as a whole because of high uncertainty of these concepts and frequently reflecting on an internal person experience. More essential reason of well-being is not the objective financial position of a person, but what subjective value it has for him and how in this connection it is estimated by him. The subjective values are often the leading factor of well-being.

Economic growth and social policy of the state should promote the increase of population standard of living. Nevertheless, it is impossible to answer unequivocally for a question whether or not it is perceived scientifically - technical progress, change of the informational environment, occurrence of the new innovative products by a separate person as an increase of his welfare.

\section{Conclusion}

Nowadays it is a very actual question of alignment of a standard of living in different countries because the gap in a standard of living between the richest and the poorest countries is huge and is still continuing to grow. Some modern Russian economists stay on different point of view about an approach to the model of welfare. Nevertheless, the majority agree with that criterion of people satisfaction of a standard of living is achievement of improvements on the most significant positions (increase in incomes of population, security habitation, the public health services) whereas equally high standard of living to reach is impossible by virtue of geographical, resource, institutional, etc. distinctions on different countries and territories. For this reason a very big role is played with social policy of the state.

Thus it is necessary to take into account, that well-being of a person depends not only on a material component and includes factors of subjective value. 
Thus, economic growth creates a material basis for increase of population well-being, but it is necessary the results redistribution of economic growth with the aim of efficiency increase of social policy from the part of the state. This policy should take into account features of different population categories and level the social and economic polarization of a society.

\section{Acknowledgements}

Authors would like to thank Tomsk Polytechnic University and the department of Economics, also the chef of department Prof. Barysheva G.A. for opportunity of leading the research.

\section{References}

Samaruha V.I., Gulyaeva L.V. (2011) The role of social services in improving the life quality. Izvestia of Irkutsk State Academy of Economics, 4, 46-50.

Leontjev D.A. (2011) Personal potential: structure and diagnostics. Publishing house "Smisl", 5-11.

Kilchukova A.L. (2012) Quality of life: structural component. Terra Economicus, 2- 2(1)

Kizhikina V.V. (2012) Welfare and quality of life of population through a prism of dynamics of a consumer market. Journal of Economics, 1, 17-24.

The social position and living standards of Russian population. Appendix to the book "The social position and living standards of the population of Russia". Federal State Statistics Service. http://www.gks.ru/wps/wcm/connect/rosstat_main/rosstat/ru/statistics/publication/catalog/doc_1138698314188 